\title{
SMES INTERNATIONALIZATION: BETWEEN STRATEGIC COLLABORATORS AND INTERMEDIARIES
}

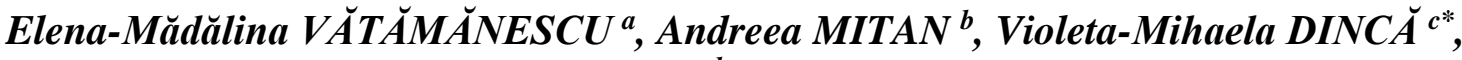 \\ Andreia Gabriela ANDREI ${ }^{d}$, Vlad-Andrei ALEXANDRU ${ }^{e}$ \\ a, b, e National University of Political Studies and Public Administration, Romania \\ ${ }^{c}$ Bucharest University of Economic Studies, Romania \\ ${ }^{d}$ Alexandru Ioan Cuza University of Iasi, Romania
}

\begin{abstract}
The internationalization process of small and medium-sized enterprises (SMEs) has been discussed in many recent studies and has triggered the attention of various professionals, international and even global organizations and authorities. Emphasis was laid on the vast array of strategies, models, forms of internationalization and their impacts on SMEs' competitive (sustainable) advantage, profitability, development and performance on foreign markets. Giving credit to the topical research in this field, the present exploratory study seeks to examine the correlations between four main factors, namely SMEs' strategic collaborators (from international business networks), intermediaries (as organizational links to the target stakeholders), the profitability resulted from international operations and the development on different foreign markets. To this end, a questionnaire-based survey was carried out with over 100 European SMEs from an industrial field. Evidence was brought that there are significant positive correlations between strategic collaborators and SMEs international profitability and development on foreign markets, whereas the use of intermediaries only correlates with the profits derived from international operations.
\end{abstract}

KEYWORDS: intermediaries, internationalization, small and medium-sized enterprises (SMEs), strategic collaborators.

\section{INTRODUCTION}

Over the past years, small and medium-sized enterprises (SMEs) taking part in international activities have attracted notable attention among scholars and professionals (Vătămănescu, Alexandru \& Gorgos, 2014; Vătămănescu et al., 2017, 2020 a, b, c, 2021). Tight cooperation between SMEs which want to expand abroad and various public or private organizations stand for a key dimension of developing a business at the international level. Some interactions are predicable to happen and therefore they are taken into account in the process of planning an overseas growth. That is normally the context where collaborating with formal establishments like government authorities and regulating bodies. Other interactions such as the ones with other SMEs or informal organizations, like civil society and community interest parties can happen either voluntarily or unexpectedly, significantly influencing the SMEs' capability to touch their objectives (Vătămănescu et al., 2020 c, d, 2021; Hossain, Azam \& Quaddus, 2021).

Customary, the internationalization process of a firm has been researched from the angle of conquering a new market. Nowadays, it is frequently researched into the network framework, which

\footnotetext{
* Corresponding author. E-mail address: violetamihaeladinca@yahoo.fr
} 
takes into consideration the significance of business connections and strategic international links (Vătămănescu et al., 2020a, b, 2021). The course of entrance is not perceived as a pathway of accessing a foreign market, but one of joining a chain of business relations in another country. Insidership in these types of business circles is fundamental for prosperous internationalization.

Bell, McNaughton, Young and Crick (2003) showed how the company's internationalization has been characterized for a long time as a gradual and evolving process, frequently placed under the framework of the Uppsala Model (Johanson \& Vahlne, 2009) or the Innovation Model (Cavusgil \& Knight, 2009), where companies follow internationalization step-by-step and in phases. These levels of expanding abroad begin with early uneven and inconstant exports for tangibly and culturally in vicinity markets ensured by more frequent exports through agents, and in the end by creating foreign branches. A structured and methodical international evolution of this kind depends on the finite and restricted access to know-how, means and funds (Vătămănescu \& Mitan, 2019). Companies dedicate themselves to break in the next level of the internationalization process if they gained pertinent and enough expertise and know-how by concluding an extensive native (regional) business timespan (Luostarinen \& Gabrielsson, 2006). Either following a network approach or a step-by-step strategy, either using strategic collaborators or intermediaries, today's SMEs are struggling to surpass the challenges of internationalization and to achieve greater performance by tackling foreign markets and by accessing the tangible and intangible resources abroad.

Given the vast array of strategies, models and forms of SMEs internationalization, the present paper intends to focus on certain factors of the internationalization process, highlighting the relationships among strategic collaborators from international business networks, intermediaries, the profits resulted from international operations and the development of the organization on foreign markets. Both the international profitability and expansion of SMEs are placed within the logic of achieving sustainable competitive advantage from accessing new tangible and intangible resources and assets abroad.

\section{THEORETICAL BACKGROUND}

The internationalization of SMEs is a multifaceted process which can assume different forms, models and strategies, according to the existing strengths and weaknesses of the organizations and to the environmental opportunities and risks (Vătămănescu \& Alexandru, 2018; Vătămănescu, Gorgos \& Alexandru, 2018; Vătămănescu, 2020; Vătămănescu et al., 2020a, b, c; Vătămănescu et al., 2021). The applied strategies may range from strategic collaborations to the usage of intermediaries, and highly depend on the managerial vision on the capitalization of firm resources and on the external benefits. The business development and growth, gaining sustainable competitive advantage, the access to more markets, the profit increase, the systemic innovation of products and services arise as strategic goals to be achieved via the internationalization endeavors (Van Gils and Zwart, 2009; Păduraru et al., 2016; Mitan \& Vătămănescu, 2019; Vătămănescu, 2020).

According to Van Gils and Zwart's (2009) view, small firms engage into an international collaboration in order to take advantage from a faster entrance on a foreign market and to fulfill economies of scale. Especially the asset of a quicker market access is essential because it lowers the uncertainties and dispenses them among the collaborators (Swoboda, Meierer, Foscht \& Morschett, 2011; Nistoreanu, Dincă and Șchiopu, 2017). Moreover, by establishing a strategic collaboration, small companies can benefit from achieving access to social, technical, financial and commercial competitive means and tools which, in standard cases, ask for a longer period of performance in order to attain those (Varis et al., 2005). Particularly this speed and willingness in getting access to the wanted and requested techniques and finances appears to be pertinent for small enterprises as their major feature and particularity is to aspire to a faster internationalization. Therefore, strategic cooperation can support small companies to surpass their impediment of being new and minor on the market and take the role of supporter and even advertiser of corporate learning and progress 
(Comi \& Eppler, 2009; Vătămănescu, Alexandru \& Andrei, 2015). Strategic partners might become of prime importance to access key information for business development (Capik \& Brockerhoff, 2017; Vătămănescu et al., 2020b, Vătămănescu et al., 2021).

The network of collaborators allows the SMEs to seize many opportunities in the market and has three main advantages: access to information, speed of information transmission and building the reputation (Håkansson et al., 2009; Andrei \& Zaiț, 2014). Especially the importance of informal networks in the process of SMEs internationalization has a special role because the exchange of contacts and the sharing of experience could be a real organizational asset. The use of informal networks provides assistance in obtaining business advice of a foreign trade expert, but also to identify new opportunities (Abrahamsen et al., 2016; Vătămănescu et al., 2016, 2017).

Even if the international markets, both public and private, offer interesting opportunities for European companies, SMEs face particular obstacles when seeking to internationalize their activities, in particular when they want to access to market information, locate potential customers or find the right partners. They are also faced with more complex issues, including compliance with laws, for example binding provisions of contract law, customs regulations, standards and technical regulations, management of technology transfers and data protection intellectual or industrial property rights (Abrahamsen et al., 2016; Vătămănescu et al., 2019 a, b).

In these areas, SMEs are generally less well-armed than large companies in terms of internal skills and financial or human resources. The main obstacles reported by SMEs are insufficient working capital to finance exports; difficulties in detecting opportunities activities abroad; insufficient information to locate /analyze markets; inability to contact potential customers abroad; difficulties in ensuring reliable representation abroad; lack of time, for leaders, for addressing internationalization issues; lack of staff, or insufficiently trained staff. Companies that are not yet active in the international market can underestimate certain obstacles and overestimate others. It is therefore advisable to take into considering the international experience of companies, or their lack of experience, time to design and set up business support services (Vătămănescu et al., 2019a,b; Vătămănescu, 2020). In their own right, Senik et al. (2011) and Dolfsma and van der Eijk (2016) highlighted the following obstacles for SMEs: the price of their product or service; the high cost of internationalization; the quality of the product and the lack of qualified staff; the specifications of the company's products; the language.

Looking into the business environment, Nguyen and Le (2019) identified some factors which may be considered as obstacles to SMEs internationalization, i.e., lack of capital; lack of adequate public support; lack of information; the cost or the difficulties related to the administrative procedures necessary to transportation; other laws and regulations in force in the foreign country; customs duties or other obstacles to trade in the foreign market; cultural differences (including the commercial culture). Similarly, Demirbag et al. (2021) investigated the relationship between the micro-foundational dimensions of firm internationalization and its knowledge management strategy in the emerging economies, which have been found more efficient in converting technology into socio-economic impact. Their results from the analysis of World Bank data collected from manufacturing firms operating in emerging economies showed that the share of foreign employees, level of foreign input and foreign sales have a significant impact on the firm's position on international markets.

The study advanced by Capik and Brockerhoff (2017) discusses the reasons behind the internationalization of British small firms activating in various business areas and investigates the importance that strategic partnerships own in the process. It revealed that strategic partnerships support small firms in overcoming financial burdens and their liability of newness and smallness. In the same time, growing the brand's notoriety, believability and reliability motivate small companies to take part in strategic partnerships from an early stage, but in the same time it draws the attention on the fact that strategic partnerships are suitable only for a particular period of time, which begins shortly after the firm's inception and ends when the firm becomes more established. 
Another strategy applied by SMEs in their process of venturing into foreign countries and markets is linked to the usage of intermediaries. These intermediaries can pave the way for the expansion process by connecting buyers with sellers and they are also in charge of looking for potential buyers/sellers, negotiating terms of trade and importing/exporting the good to the end user (DekelSachs et al., 2021). In this sense, a study carried out by Małys and Fonfara (2019) on Polish food companies pointed to the importance of developing a strong relationship with one actor, who acted as key intermediary with the market versus developing a number of weaker links with various actors.

The intermediaries can offer the firms worthy resources like information about the market with the aim of acknowledging and reducing foreign operations costs, and they are representatives for the activities for the newcomer which can be very important for the firm's achievements in the context when overcoming that status can be troublesome because of institutional constraints. There are situations where local business systems have firm and entangled engagement, it may be a difficult task for a total 'foreigner' to acquire insidership without referring to an intermediary (Apaydin, Thornberry \& Sidani, 2020).

Using Italian customs data between 2015 and 2020, we can take into account companies with wholesaling as their main activity as intermediaries. For 2015-2020, the vast part of exports, more than $85 \%$, are performed directly by manufacturing companies that account more than $55 \%$ of exporters. The $27 \%$ of exporters that are wholesalers account for no more than $10 \%$ of Italian exports during this period. As in other countries, retailers are relatively minor players in exporting, accounting for less than one per cent of exports by value. Apart from that, Italian data point out that intermediaries play a significant part for imports. They sum up for 35\% of importers and their share in import value is around 35\% (World Bank, 2020). When it comes of France's data for the year 2020 , intermediaries represented $32 \%$ of the exporters, a figure in range with that acknowledged by Italy or the US, but appraised for a bigger share of export value, around $20 \%$ in comparison with the $10 \%$ of the other two states. This is an evolution for France parallel to 2015 when trade intermediaries made around 17\% of total French exports (European Commission, 2021).

If we look into the literature dedicated to the significance of intermediaries for SMEs, a study carried out on 165 international venture managers (of SMEs) showed that a good relationship between the respective SMEs and their intermediaries can increase SMEs performance, expansion and profit (Efrata \& Øynab, 2020). Another study carried out by Apaydin (2020) used the case analysis approach to underline the importance of bazaars (informal networks of local merchants) in Iran and their positive impact on performance and survival of an international subsidiary opened in Iran (Apaydin et al., 2020). In some countries, intermediaries can be wide and dense and cover all strands of society, including powerful politicians. Accessing such intermediaries becomes a significant strategic choice and the best examples standing are the guanxi system in China, yongo in Korea or jinmyaku in Japan (Li et al., 2019).

Based on the theoretical considerations depicted above, we infer that:

H1: Strategic collaborators positively correlate with the use of intermediaries in SMEs internationalization process.

H2: SMEs' profitability from international operations positively correlates with their development on foreign markets.

H3: Strategic collaborators positively correlate with SMEs' profitability from international operations.

H4: Intermediaries positively correlate with SMEs' profitability from international operations.

H5: Strategic collaborators positively correlate with SMEs' development on foreign markets.

H6: Intermediaries positively correlate with SMEs' development on foreign markets. 


\section{METHOD}

A comprehensive online questionnaire was applied in 2019 on a convenience sample covering 102 European SMEs operating in the steel industry. Top managers or business owners from these organizations agreed to participate in the survey. The participants came from different countries, most of them being between 35 and 55 years old, having postgraduate studies and more than 5 years of experience in the actual position.

The research instrument comprised over than 100 items related to strategic and operational aspects of SMEs expansion on international markets. The items were measured on 1 to 7 Likert scales. For the present scrutiny, the focus is on the contributions of strategic collaborators (Collaborators variable) and intermediaries (Intermediaries variable) as facilitators of SMEs' development on international markets (Markets_int variable) and profitability achieved through international operations (Profits_int variable). Therefore, only four variables were investigated in this study.

The analysis of the data was performed using SPSS software, and the scope of investigation was to assess the correlation relationships between the four variables of interest: Collaborators, Intermediaries, Markets_int and Profits_int. The Pearson correlation coefficient was used as the adequate statistical test given the nature of the items.

\section{RESULTS}

Linear correlation analysis was used to assess the relationships between SMEs' development on international markets (Markets_int variable), the proportion of SMEs' profits resulted from international operations (Profits_int variable), the use of the intermediaries as facilitators of SMEs' exports (Intermediaries variable), and the use of strategic collaborations with specific partners operating on the external markets (Collaborators variable). A bootstrap procedure with 1000 resamples was included in the analysis to increase the accuracy of the estimation. The results are detailed in Table 1.

Table 1. Results of correlation analysis

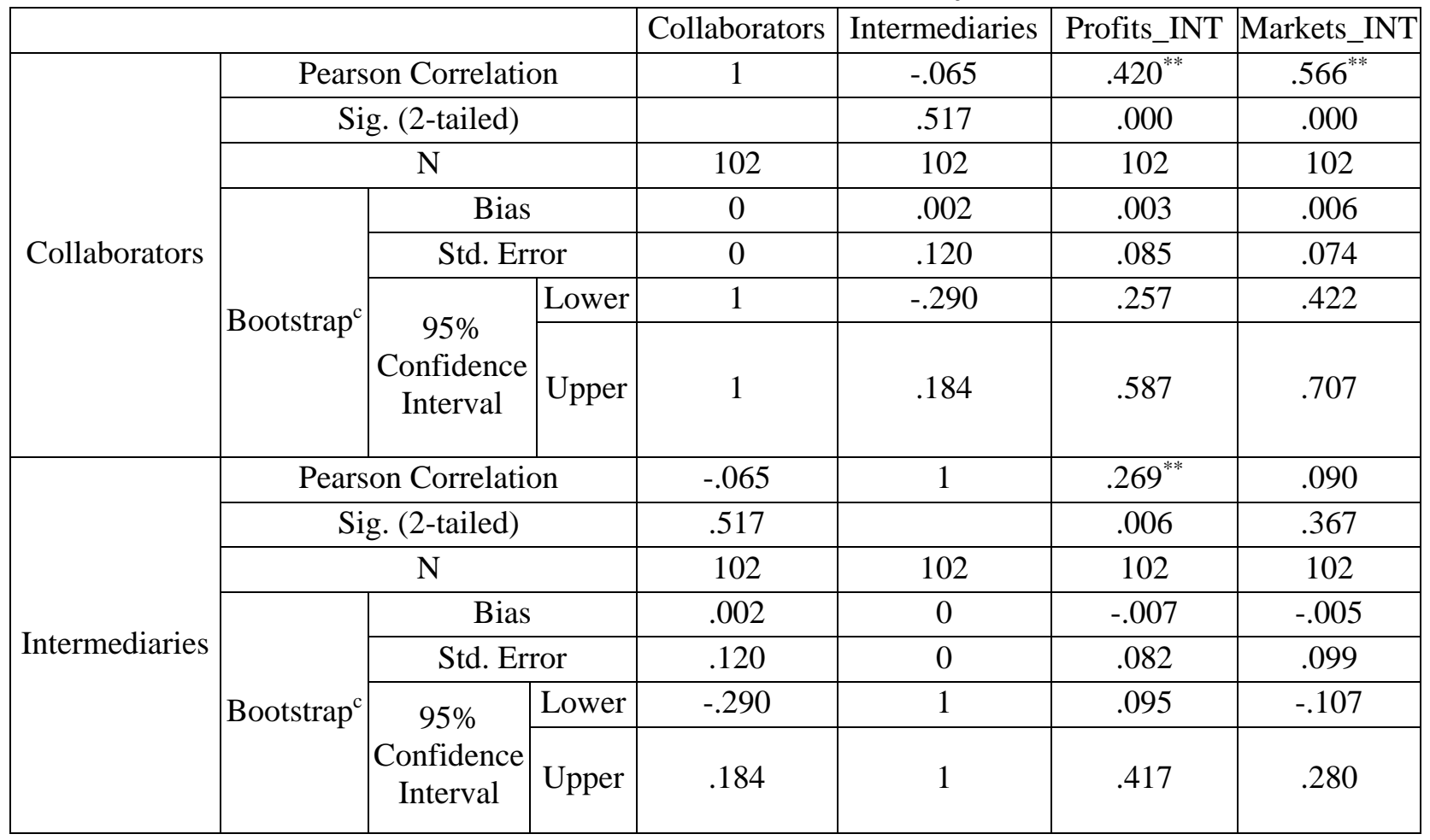


"Managing People and Organizations in a Global Crisis" $4^{\text {th }}-5^{\text {th }}$ November 2021, BUCHAREST, ROMANIA

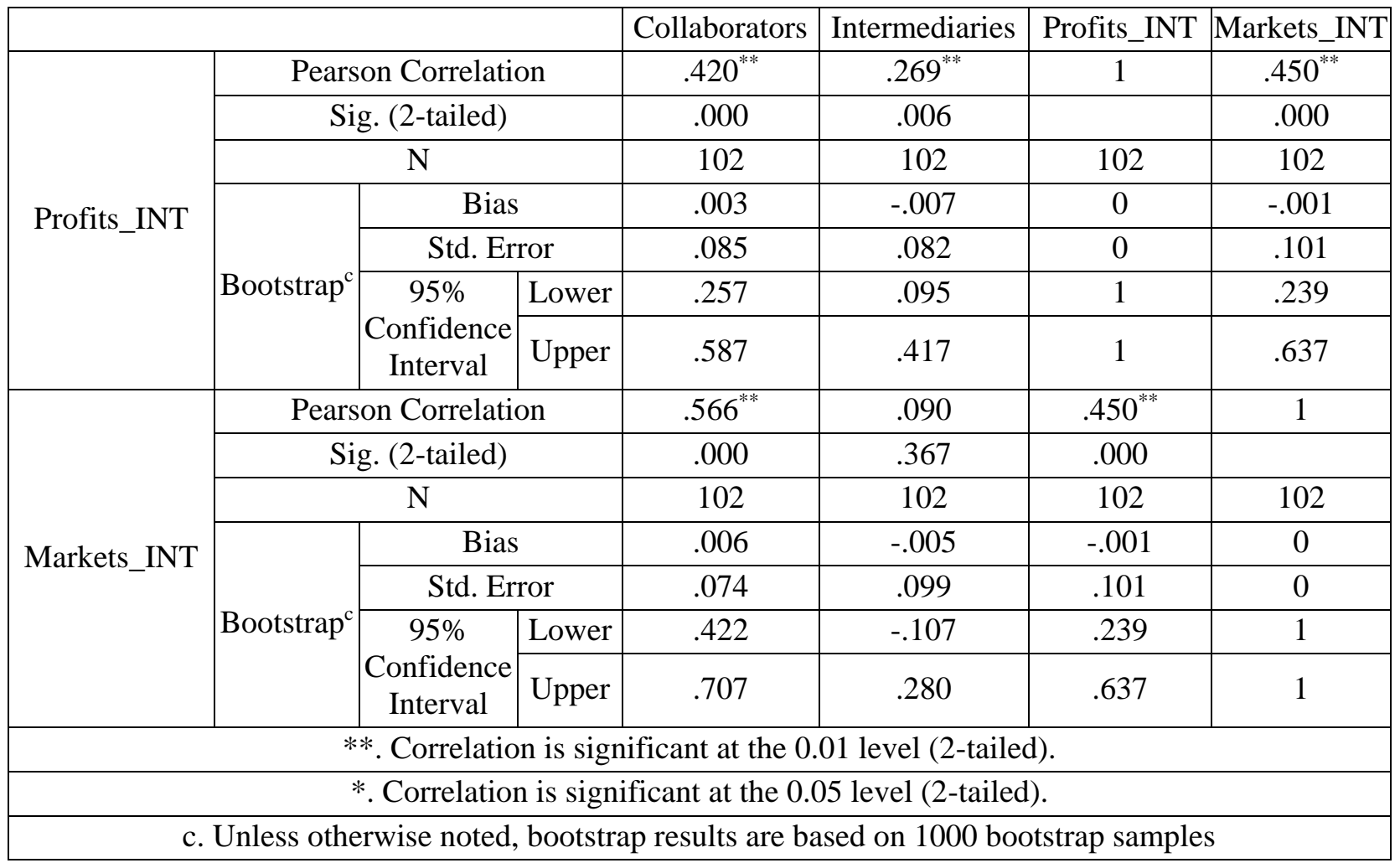

The statistical analysis revealed four positive and significant correlations, one positive but nonsignificant correlation, and one non-significant negative correlation.

The negative correlation between Collaborators and Intermediaries variables (negative correlation coefficient Pearson's $r=-0.065$; non-significant at 0.05 level) highlights the fact that although many companies are using both strategic collaborations and intermediaries in their export-related activities, the companies relying on strategic collaborations turn to intermediaries to a lesser extent, and vice versa, those relying on intermediaries as exports facilitators, lack strategic collaborators in external markets. Thus, $\mathrm{H} 1$ is not supported. On the positive side of relationships, the results have shown a strong positive correlation (Pearson's $r=0.450$, significant at the $p<0.01$, out of zero 95\% confidence interval [0.239, 0.637]) between SMEs' development on international markets (Markets_int variable) and the proportion of SMEs' profits resulted from international operations (Profits_int variable), confirming H2.

The strongest positive correlation was found between Markets_int variable as a measure of SMEs' development on international markets considering the number of foreign markets where the organization is present, and Collaborators variable measuring the strategic collaborations with specific partners operating on the external markets (Pearson's $r=0.566$, significant at the $p<0.01$, with out of zero $95 \%$ confidence interval $[0.422,0.707]$ resulted from bootstrapping procedure). Thus, H5 is supported. Also, the results indicated a strong positive correlation between the proportion of SMEs' profits derived from international operations (Profits_int variable) and the use of the strategic collaborators from the external markets (Collaborators variable) - see Table 1 and correlation coefficient Pearson's $\mathrm{r}=0.420$, significant at the $\mathrm{p}<0.01$, and out of zero 95\% confidence interval $[0.266,0.586]$ resulted from bootstrapping procedure. Hence, $\mathrm{H} 3$ is also supported.

Correlation coefficient Pearson's $r=0.269$, significant at the $\mathrm{p}<0.01$, and the out of zero 95\% confidence interval $[0.095,0.425]$ indicates a significant positive correlation between the proportion of SMEs' profits resulted from international operations (Profits_int variable) and the use of the intermediaries as facilitators of SME's exports (Intermediaries variable), confirming H4. Still, no 
significant correlation was found between Intermediaries variable and Markets_int variable, measuring SMEs' development on international markets considering the number of foreign markets where the organization is present. Statistics indicate a non-significant correlation coefficient Pearson's $r=0.090(p>0.05)$ with zero value inside the $95 \%$ confidence interval $(-0.107,0.277)$ between Intermediaries variable and Markets_int variable. Therefore, H6 is not supported by the empirical data.

Overall, the statistical analysis has shown that SMEs' profitability resulted from international operations (Profits_int variable) and the development of foreign markets where the organization is present (Markets_int variable) are highly correlated with the use of strategic collaborators (Collaborators variable), while the use of intermediaries (Intermediaries variable) correlates solely with the profitability achieved through international operations (Profits_int variable).

The current findings are mostly in line with previous research contending the important role of strategic collaborators and intermediaries in achieving profitability at the international level in the case of SMEs (Swoboda, Meierer, Foscht \& Morschett, 2011; Capik \& Brockerhoff, 2017; Vătămănescu \& Alexandru, 2018; Vătămănescu et al., 2020 a, b, c; Vătămănescu et al., 2021). The same applies to the correlation between strategic collaborators and SMEs development on the foreign markets (Păduraru et al., 2016; Vătămănescu et al., 2019a, b). The findings do not support prior research (Li et al., 2019; Efrata \& Øynab, 2020; Apaydin, 2020) which have underscored the role of intermediaries in the internationalization process of SMEs and in their venture into foreign markets.

\section{CONCLUSIONS}

The unfolding of the empirical research has brought evidence in support of testing the inferred relations. In this front, the data showed that four hypotheses were supported and that strategic collaborators from international business networks have an important role for the competitive advantage of SMEs when it comes to international expansion and profitability.

Even though the results validate most of the formulated assumptions, the study is not exempted from limitations which should be addressed by further research. On the one hand, the research sample only comprised enterprises from a single field which has clear specificities. On the other hand, the exploratory nature of this study requires future in-depth analyses on the topic to better examine the underlying relationships between the considered factors.

\section{ACKNOWLEDGMENT}

This work was supported by a grant of the Romanian Ministry of Education and Research, CNCS UEFISCDI, project number PN-III-P1-1.1-TE-2019-1356, within PNCDI III.

\section{REFERENCES}

Abrahamsen, M., H., Henneberg, S., C. \& Huemer L. (2016). Network picturing: An action research study of strategizing in business networks. Review article. Industrial Marketing Management, 59, 107-119.

Andrei, A., G. \& Zaiţ, A. (2014). Branding insights: an interdisciplinary journey from perception to action. In Bratianu, C., Zbuchea, A., Pinzaru, F. \& Vătămănescu, E., M. (Eds.) Strategica: Management, Finance, and Ethics (pp. 593-604). Bucharest: Tritonic.

Apaydin, M., Thornberry, J. \& Sidani, Y., M. (2020). Informal Social Networks as Intermediaries in Foreign Markets. Management and Organization Review, 16(3), 629-656, doi: 10.1017/mor.2020.17. 
Bell, J., McNaughton, R., Young, S. \& Crick, D. (2003). Towards an integrative model of small firm internationalization. Journal of International Entrepreneurship, 1(4), 339-362.

Capik, P. \& Brockerhoff, A. (2017). The Role of Strategic Partnerships in the Internationalization of Small Born Global Firms. Entrepreneurial Business and Economics Review, 5(3), 49-77.

Cavusgil, S., T. \& Knight, G. (2009). Born Global Firms: A New International Enterprise. New York: Business Expert Press.

Comi, A. \& Eppler, M., J. (2009). Building and Managing Strategic Alliances in TechnologyDriven Start-Ups: A Critical Review of Literature. Lugano: Institute of Marketing and Communication Management (IMCA).

Dekel-Sachs, O. et al. (2021). Searching for a new perspective on institutional voids, networks and the internationalization of SMEs in emerging economies: a systematic literature review, International Marketing Review, Vol. ahead-of-print, No. ahead-of-print, doi:10.1108/IMR-122020-0303.

Demirbag, M., Apaydin, M. \& Sahadev, S. (2021). Micro-foundational dimensions of firm internationalization as determinants of knowledge management strategy: A case for global strategic partnerships. Technological Forecasting and Social Change, 165(C). https://doi.org/10.1016/j.techfore.2020.120538.

Dolfsma, W. \& van der Eijk, R. (2016). Network position and firm performance - the mediating role of innovation. Technology Analysis \& Strategic Management, 29(6), 556-568.

Efrata, K. \& Øynab, S. (2020). An interaction orientation approach to SME-Intermediaries relationships. European Management Journal. https://doi.org/10.1016/j.emj.2020.10.004.

European Commission (2021). Euro area international trade in goods surplus $€ 6.3$ bn. Retrieved from https://ec.europa.eu/eurostat/documents/2995521/11562995/6-18032021-BP-EN.pdf.

Håkansson, H., Ford, D., Gadde, L., E., Snehota, I. \& Waluszewski, A. (2009). Business in Networks. Chichester: John Wiley \& Sons.

Hossain, M., I., Azam, M., S. \& Quaddus, M. (2021). Small firm entry to e-marketplace for market expansion and internationalization: A theoretical perspective. Journal of International Entrepreneurship 1, 1-31.

Johanson, J. \& Vahlne, J. (2009). The Uppsala internationalization process model revisited: From liability of Foreignness to Liability of Outsidership. Journal of International Business Studies, 40(9), 1411-1431.

Li, P., P., Zhou, S., S., Zhou, A., J. \& Yang, Z. (2019). Reconceptualizing and redirecting research on guanxi: 'guan-xi' interaction to form a multicolored Chinese knot. Management and Organization Review, 15(3), 643-677.

Luostarinen, R. \& Gabrielsson, M. (2006). Globalization and marketing strategies of born globals in SMOPECs. Thunderbird International Business Review, 48(6), 773-801.

Małys, L. \& Fonfara, K. (2019). From Intermediary Relationship to Multiple Relationships Option of Developing the Network Position in the Internationalization Process. An Exploratory Study of a Polish Food Company. Olsztyn Economic Journal, 14(2), 209-221.

Mitan, A. \& Vătămănescu, E., M. (2019). Romanian SMEs Internationalization in the Light of Internal Capabilities and External Conditions. A Secondary Data Analysis. Management Dynamics in the Knowledge Economy, 7(4), 485-501. doi: 10.25019/MDKE/7.4.03.

Nguyen, H., T. \& Le, V. (2019). Network ties and export propensity of Vietnamese small and medium enterprises. Asia Pacific Business Review, 25(1), 100-122.

Nistoreanu, P., Dincă, V., M. \& Șchiopu, A., F. (2017). Competition Policy in the European Film Industry Focused on Consumers' Interests - a Romanian Perspective. Amfiteatru Economic, 19(45), 397-413.

Păduraru, T., Vătămănescu, E., M., Andrei, A., G., Pînzaru, F., Zbuchea, A., Maha, L,G. \& Boldureanu, G. (2016). Sustainability in Relationship Marketing: An Exploratory Model for the 
Industrial Field. Environmental Engineering and Management Journal, 15(7), 1635-1647. Retrieved from http://omicron.ch.tuiasi.ro/EEMJ/pdfs/accepted/569_226_Paduraru_15.pdf.

Senik, Z., C., Scott-Ladd, B., Entrekin, L. \& Adham, K. (2011). "Networking and internationalization of SMEs in emerging economies", Journal of International Entrepreneurship, 9(4), 259-281.

Swoboda, B., Meierer, M., Foscht, T. \& Morschett, D. (2011). International SME Alliances: The Impact of Alliance Building and Configurational Fit on Success. Long Range Planning, 44(4), 271-288.

Van Gils, A. \& Zwart, P., S. (2009). Alliance Formation Motives in SMEs: An Explorative Conjoint Analysis Study. International Small Business Journal, 27(1), 5-37.

Varis, J., Kuivalainen, O. \& Saarenketo, S. (2005). Partner Selection for International Marketing and Distribution in Corporate New Ventures. Journal of International Entrepreneurship, 3(1), 19-36.

Vătămănescu, E., M., Alexandru, V., A. \& Gorgos, E., A. (2014). The Five Cs Model of Business Internationalization (CMBI) - a preliminary theoretical insight into today's business internationalization challenges. In Brătianu, C., Zbuchea, A., Pînzaru, F. \& Vătămănescu, E.M. (Eds.). Strategica. Management, Finance, and Ethics, pp. 537-558, Bucharest, Tritonic.

Vătămănescu, E., M., Alexandru, V., A. \& Andrei, A., G. (2015). The relational leader. A preliminary framework for corporate intercultural accommodation. In Brătianu, C., Zbuchea, A., Pînzaru, F., Vătămănescu, E., M. \& Leon, R., D. (Eds.), Strategica. Local versus Global, pp. 303-312, Bucharest, Tritonic.

Vătămănescu, E., M., Zbuchea, A., Pînzaru, F. \& Andrei, A., G. (2016). The Impact of Relational Capital on SME Internationalization. Leveraging Online Versus Offline Business Networking. In Moffett, S., \& Galbraith, B. (Eds.), Proceedings of the 17th European Conference on Knowledge Management, pp. 926-935, Reading, UK, Academic Conferences and Publishing International Limited.

Vătămănescu, E., M., Andrei, A., G., Nicolescu, L., Pînzaru, F. \& Zbuchea, A. (2017). The Influence of Competitiveness on SMEs Internationalization Effectiveness. Online versus Offline Business Networking. Information Systems Management, 34(3), 205-219. Retrieved from http://www.tandfonline.com/doi/full/10.1080/10580530.2017.1329997.

Vătămănescu, E., M. \& Alexandru, V., A. (2018). Beyond Innovation: The Crazy New World of Industrial Mash-ups. In Vătămănescu, E., M. \& Pînzaru, F. (Eds.), Knowledge Management in the Sharing Economy - Cross-Sectoral Insights into the Future of Competitive Advantage, pp. 271-285, Cham: Springer International Publishing.

Vătămănescu, E., M., Gorgos, E., A. \& Alexandru, V., A. (2018). Theoretical Insights into SMEs' Opportunities and Vulnerabilities in International Settings. In Bratianu, C., Zbuchea, A. \& Vițelar, A. (Eds.), Strategica. Challenging the Status Quo in Management and Economics, pp. 979-988, Bucharest, Tritonic.

Vătămănescu, E., M. \& Mitan, A. (2019). From In-House towards International Contexts. An Insight into Romanian SMEs Internationalization. In Bratianu, C., Zbuchea, A., Hrib, B., Vițelar, A. \& Anghel, F. (Eds.), Strategica. Upscaling Digital Transformation in Business and Economics, pp. 503-513, Bucharest, Tritonic.

Vătămănescu, E., M., Dincă, V., M., Andrei, A., G. \& Alexandru, V., A. (2019a). Strategic Networks and Innovative Performance: a Relational Design of Knowledge Sharing in Small and Medium-Sized Enterprises. In Schiuma, G., Demartini, P. \& Yan, M., R. (Eds.), Proceedings IFKAD 2019. Knowledge Ecosystems and Growth, pp. 2084-2094, Matera, Institute of Knowledge Asset Management.

Vătămănescu, E., M., Gorgos, E., A., Ghigiu, A., M. \& Pătruț, M. (2019b). Bridging Intellectual Capital and SMEs Internationalization through the Lens of Sustainable Competitive Advantage: 
A Systematic Literature Review. Sustainability, $\quad 11(9), \quad 2510$. https://doi.org/10.3390/su11092510.

Vătămănescu, E., M. (2020). Internaţionalizarea IMM-urilor și marketingul relaţional: între convergenţă și conectivitate. The internationalization of SMEs and relationship marketing: between convergence and connectivity, Bucharest, Pro Universitaria.

Vătămănescu, E., M., Alexandru, V., A., Gorgos, E., A. \& Mitan, A. (2020a). Filling the Gaps. Intellectual Capital and the Internationalization of European SMEs. Saarbrucken: Lambert Academic Publishing.

Vătămănescu, E., M., Cegarra-Navarro, J., G., Andrei, A., G., Dincă, V., M. \& Alexandru, V., A. (2020b). SMEs strategic networks and innovative performance: a relational design and methodology for knowledge sharing. Journal of Knowledge Management, 24(6), 1369-1392. https://doi.org/10.1108/JKM-01-2020-0010.

Vătămănescu, E., M., Alexandru, V., A., Mitan, A. \& Dabija, D., C. (2020c). From the deliberate managerial strategy towards international business performance: A psychic distance vs. global mindset approach. Systems Research and Behavioral Science, 37(2), 374-387. https://doi.org/10.1002/sres.2658.

Vătămănescu, E., M., Mitan, A., Dincă, V., M. \& Andrei, A., G. (2020d). Integrating intellectual capital and SMEs internationalization into a common conceptual framework. In Bratianu, C., Zbuchea, A., Anghel, F. \& Hrib, B. (Eds.), STRATEGICA. Preparing for Tomorrow, Today, pp. 792-805, Bucharest, Tritonic.

Vătămănescu, E., M., Mitan, A., Andrei, A., G. \& Ghigiu, A., M. (2021). Linking coopetition benefits and innovative performance within small and medium-sized enterprises networks: a strategic approach on knowledge sharing and direct collaboration. Kybernetes, Ahead-of-print. https://doi.org/10.1108/K-11-2020-0731.

World Bank Group (2020). Trading for Development in the age of global value chains - world development report. Retrieved from https://openknowledge.worldbank.org/handle/10986/ 32437. 